\title{
Connected Vessels: West Asia and East Asia in China's Geopolitics
}

\section{Vasijas conectadas: Asia Occidental y Asia Oriental en la Geopolítica de China}

\author{
Yitzhak Shichor ${ }^{1}$ \\ The Hebrew University of Jerusalem \\ The University of Haifa (Israel)
}

Recibido: 13-12-15

Aprobado: 31-12-15

\begin{abstract}
East Asia and West Asia (the Middle East) ${ }^{2}$ are usually treated in the academic literature as two distinct and separate issues in Chinese foreign policy. Studies of China's policy in East Asia hardly mention the Middle East and studies of the Middle East hardly mention East Asia. In fact, these two regions are not simply interconnected in China's geopolitical outlook but provide clues to understanding Beijing's foreign policy toward each of them -they are interdependent. As such, they are connected vessels in the sense that the situation in one region affects, or even determines, China's policy in the other. This is evident in a number of perspectives: strategy, economics, energy, military and Islam. Mutual dependence is one of the features of contemporary international relations, after the end of the Cold War. While usually it is limited to one aspect or two (primarily economic and military), in the case of China and the Middle East, mutual regional dependence involve a number of levels.
\end{abstract}

\footnotetext{
${ }^{1}$ (msshic@mail huji.ac.il) This article is a substantially expanded version of a lecture delivered at the Asia Studies Center, Boğazici University, Istanbul, 15 April 2015. Some recent publications by Shichor: Edited books, "All under Heaven": History of the Chinese Empire, Vol. I, The Emergence of the Chinese Empire (Ra'anana: the Open University, 2011), 422p., Vol. II, The Early Chinese Empire (Ra'anana: the Open University, 2013), 670p., in Hebrew; with Jonathan Goldstein, China and Israel, 1948-2015 (Jerusalem: the Magnes Press, 2016, 312p.), in Hebrew. Articles: "Sino-American Crosscurrents in the Middle East: Perceptions and Realities," in: Niv Horesh (Ed.), Toward Well-Oiled Relations? China's Presence in the Middle East Following the Arab Spring (New York: Palgrave Macmillan, 2015), pp. 5-18; "Chinese-Israeli Relations in a Middle Eastern Context: Retrospect and Prospects," Mediterranean Quarterly, Vol. 26, No. 1 (March 2015), pp. 137-151; "Striking When the Iron Is Cold: Moshe Sharett and Sino-Israeli Relations," Israel Studies, Vol. 20, No. 3 (Fall 2015), pp. 102-130; "Pawns in Central Asia's Playground: Uyghurs between Moscow and Beijing," East Asia, Vol. 32, No. 2 (2015), pp. 101116; "See No Evil, Hear No Evil, Speak No Evil: Middle Eastern Reactions to Rising China's Uyghur Crackdown," Griffith Asia Quarterly, Vol. 3, No. 1 (January 2015), pp. 62-85.

${ }^{2}$ There are various definitions of the Middle East. For the purpose of this article it covers most of the Arab League members, including North Africa and Sudan, as well as Turkey and Iran. Officially, the Chinese also use the term West Asia.
} 
Key-words: West Asia, East Asia, Middle East, China, Geopolitics, Foreign policy.

\section{Resumen}

Las regiones de Asia Oriental y Asia Occidental (Oriente Medio) son normalmente tratadas en la literatura académica como dos asuntos separados y distintos dentro de la política exterior china. Los estudios acerca de la política de China en Asia Oriental apenas si mencionan Oriente Medio, mientras que los estudios de Oriente Medio apenas mencionan Asia Occidental. Pero de hecho ambas regiones no sólo están interconectadas en la visión geopolítica de China sino que proporcionan claves para entender la política exterior de Beijing hacia cada una de ellas - esto es, ambas regiones son interdependientes. Como tales, son vasos conectados en el sentido de que la situación en una afecta, e incluso determina, la política de China con respecto a la otra. Esto es evidente desde diversas perspectivas: estratégicas, económicas, energéticas, militares, e incluso con respecto al Islam. La mutua dependencia es una de las características de las relaciones internacionales contemporáneas desde el final de la Guerra Fría, y mientras normalmente está limitada a uno o dos aspectos (fundamentalmente económico y militar), en el caso de China y Oriente Medio, la mutua dependencia regional implica bastantes niveles.

Palabras-clave: Asia Occidental, Asia Oriental, Oriente Medio, China, Geopolítica, Política exterior.

\section{Introduction}

Since the collapse of the Soviet Union and the emergence of China there has been a good deal of discussion in academic circles and the media about the coming transformation of the international system. As the bipolar system suddenly disintegrated, the United States has become - by default rather than by plan- the focus of a unipolar system, as no other power had the capability, or the will, to occupy the other pole. Indeed, this fragmentation and devolution of international power had triggered, well before the Soviet collapse, calls to restructure the international system along multipolar lines. China and other countries preferred a multipolar system to a bipolar, let alone a unipolar system ${ }^{3}$. Officially, China

\footnotetext{
3 See, for example: Randall L. Schweller and Xiaoyu Pu, “After Bipolarity: China's Vision of International Order in an Era of U.S. Decline," International Security, Vol. 36, No.1 (Summer 2011), pp. 41-72; Brantly Womack, “Asymmetry Theory and China's Concept of Multipolarity,” Journal of Contemporary China, Vol, 13, No. 39 (May 2004), pp. 351-366; Yong Deng and Thomas G. Moore, "China Views Globalization: Toward a New great-Power Politics?", The Washington Quarterly, Vol. 27, No. 3 (Summer 2004), pp. 117-136.
} 
still favors a multipolar system, yet, willingly or not, the world is becoming bipolar again. For all its economic difficulties and international weaknesses, the US is still the leading superpower militarily, politically and economically -notwithstanding perceptions to the contrary ${ }^{4}$. Still reluctant to occupy the other pole, China is nevertheless definitely on its way to become a superpower, second only to the US - at least for a while. With initial signs- primarily, but not only, economic-already evident, bipolarity is back.

It is, however, a different bipolar system. Earlier bipolarity was an exclusive system with little interaction between the two superpowers. It was inconceivable for the US to invest in the USSR, set up aircraft or car enterprises or sell IBM to the Russian. Similarly, one could not have imagined Moscow turning the US into its biggest export market, forging a huge trade surplus and buying hundreds of billions of dollars of American bonds. This is exactly the nature of Sino-American relations, which means that current bipolarity, on the other hand, is an inclusive system. China and the US have become much intertwined and interdependent with extensive mutual investment and trade. While both have a lot to lose in case of a confrontation, they remain tough competitors in many parts of the world -in particular in East Asia- and in many spheres, short of war. Regardless of their presumed rivalry, and in view of its economic (and political) rise, Beijing is urged to share with the US responsibility for settling outstanding global and regional problems, including Middle Eastern conflicts ${ }^{5}$.

While Washington's global and regional role is widely recognized on the basis of reality and performance going back to World War II if not before, Beijing's global and regional role is becoming widely recognized on the basis of image and perceptions that still reflect virtual beliefs. Public opinion polls indicate that many in the world, primarily in the West (including the US) but also in other regions (including the Middle East), claim that China is already the leading economic power, or even the superpower, in the world -or about to become one soon. According to Pew Research Center, in November 2013 48 percent of the respondents said that China was the world's top economic power (31 percent said the US). Yet, 68 percent believed that the US was the leading military power ( 14 percent said China and only 6 percent said Russia $)^{6}$. To be sure, China does not display the traditional prerequisites commonly associated with a superpower (first and foremost global military capabilities

4 “America's Global Image Remains More Positive than China's, But Many See China Becoming World's Leading Power," Pew Research Center (18 July 2013); 2006-2011 Annual Arab Public Opinion Polls, University of Maryland.

5 Robert Zoellick, "Whither China: From Membership to Responsibility?" The National Committee on US-China Relations, New York, 21 September 2005; Bates Gill, "China Becoming a Responsible Stakeholder," 21 June 2007, in: www.carnegieendowment.org/files/Bates_paper.pdf.

${ }^{6}$ More details in: Yitzhak Shichor, "Sino-American Crosscurrents in the Middle East: Perceptions and Realities," in: Niv Horesh (Ed.), Toward Well-Oiled Relations? China's Presence in the Middle East following the Arab Spring (New York: Palgrave Macmillan, 2015), pp. 5-18. 
and overseas military bases). Moreover, Beijing is still reluctant to become a superpower, at least in the traditional sense. Nevertheless, the fact that so many outsiders now recognize and perceive China as a superpower is enough to turn it into one, though with a different style ${ }^{7}$. This assumption is based on the "recognition" theories of Charles Taylor, a Canadian political philosopher and professor emeritus at McGill University. I am adapting his theories, that concern multicultural societies, to the international system ${ }^{8}$.

According to conventional wisdom, China's gradual emergence as a global power since the early 1980s, certainly in economic terms, has inevitably led to a clash of civilizations and conflict of interests with the United States. This clash has entailed tough competition in different parts of the world, not only in East Asia (traditionally considered a sphere of Chinese influence) or in South America (traditionally considered a sphere of American influence), but also in other regions such as Central Asia, Africa -and the Middle East. China's foreign policy is usually treated on a regional basis (South America, Europe, the Middle East, Central Asia, etc.), as if Beijing has different and unrelated foreign policies. In fact, all these regional policies -including the Middle East- are related, in one way or another, to East Asia, which is the key for understanding Beijing's overall foreign policy. This apparently conventional wisdom draws from historical legacies, dating back before 1949 and after. This article aims at underlining that China's policy in East Asia and West Asia (known as the Middle East) that seems departmentalized, by no means imply that these two regions are separated in China's geopolitical outlook. In fact, they are not just interconnected but, even more so, interdependent in a number of critical dimensions that include strategy, economy, energy, military, international organizations, Islam, terrorism and, finally, a (negative) model.

\section{The Strategic Connection}

Until the $19^{\text {th }}$ century, East Asia (and to a lesser extent Central Asia) had been a sphere of Chinese influence based mainly on what is called today "soft power." China had been recognized, willingly or not, by the regional countries and tribes as a hegemonic power not so much because of its military strength -that occasionally proved inferior to its adversaries'- but because of its size, economic prosperity and cultural superiority, as reflected in its neighbors borrowing the Chinese script, classical literature, bureaucratic model, examinations system, architectural and gardening styles, Buddhist

\footnotetext{
7 See also: Hu Angang, China in 2020: A New Type of Superpower (Washington: The Brookings Institute, 2011).

${ }^{8}$ Charles Taylor, Multiculturalism: Examining the Politics of Recognition (Princeton: Princeton University Press, 1994). My study of "China as a Superpower: Exogenous Dimensions" is in progress. 
interpretations, and Neo-Confucian doctrines. China's regional hegemony collapsed in the $19^{\text {th }}$ century when the imperialist powers -Great Britain, France, Germany, Holland, Russia and, to a lesser extent, the US- not only tore Imperial China itself to pieces but divided the rest of East Asia among them. Once the Middle Kingdom, an empire that had been the hegemon in East Asia, China was reduced to a shadow of itself, forced to fight two survival wars at times simultaneously with Japan and the Communists, as well as deal with local military strongmen and foreign concessions.

By the time the People's Republic of China (PRC) was finally proclaimed on October 1, 1949, all colonial powers had lost -or were about to lose- their traditional presence and prominence in East Asia -all, but the US (and Russia) ${ }^{9}$. Their former hegemony has been appropriated by the US, denying the PRC the opportunity to regain its territorial integrity and to reassert its traditional regional preeminence. As Beijing's sphere of influence was diminishing, the US has become the predominant regional power having set up a ring of military bases in the Philippines, Japan, South Korea, Taiwan, South Vietnam and Hong Kong, leading to the virtual encirclement of China and blocking its attempts to restore its traditional rule over Taiwan, which is the ultimate symbol of China's territorial integrity. Beijing's concern about the US military deployment around China can be appreciated by referring to the American response to the deployment of Soviet missiles in Cuba in 1962. Extremely sensitive to hostile presence nearby, Washington, which forced Moscow (at a cost) to withdraw its missiles from Cuba, disregards Beijing's similar sensitivities. While the US lost some of its bases in East Asia (South Vietnam, Taiwan, the Philippines and Hong Kong) - the US still maintains its military presence in the region as the paramount obstacle to Beijing's East Asian ambitions, notwithstanding its spectacular emergence as an upcoming superpower ${ }^{10}$.

It is this obstacle that ultimately underlies and determines much of China's foreign policy in general, and Sino-US relations in particular, also in the Middle East. In spite of their impressive military modernization over the last three decades, there is however very little the Chinese can do to offset this threat directly. One option Beijing already undertakes is using its phenomenal economic power to coopt and incorporate regional countries into its economic and political orbit. Another option, more subtle and implicit, is associated with the Middle East. The correlation between this region and East Asia in China's strategic outlook is by no means a

\footnotetext{
${ }^{9}$ Arthur Cotterell, Western Power in Asia: Its Slow Rise and Swift Fall, 1415 - 1999 (New York: John Wiley, 2009).

10 John J. Mearsheimer, "The Gathering Strom: China's Challenge to US Power in Asia," The Chinese Journal of International Politics, No. 3 (2010), pp. 381-396. Many US scholars and politicians tend to ignore this. See: Mel Gurtov, "The Uncertain Future of a 'New Type' of US-China Relationship," The Asia-Pacific Journal, Vol. 11, Issue 52, No. 1 (30 December 2013).
} 
new notion. As early as World War II the Chinese Communists had become concerned that a German seizure of the Middle East could have opened the doors to Central Asia and to an eventual German-Japanese encirclement of China ${ }^{11}$. The same concerns emerged in the $1950 \mathrm{~s}$-this time about the US prominence in the Middle East and the build-up of US-inspired regional alliances (e.g. the Baghdad Pact, CENTO, and SEATO), aimed at encircling China ${ }^{12}$. The same concern was underlined in the mid-1960s when the Chinese found themselves, following the Sino-Soviet conflict, even more isolated in the world while their radical policies reigned at home and abroad.

Mao's China has always regarded US presence in the Middle East as a link in a ring that encircled China and a barrier for denying its access into the region. This struggle was by no means symmetrical. While the US - a relatively newcomer to the Middle East that had managed to reduce the influence of the traditional powers (England and France)- could provide substantial political, economic and military support to its allies there, the Chinese could do little, if anything, in these respects - except for offering ideological and rhetorical advice that ultimately failed to earn them any significant say in regional affairs. Mao's China was a marginal player in the Middle East, at best, and no direct challenge for the US ${ }^{13}$. Indirectly, Beijing had assigned this mission to regional "national liberation movements" and "revolutionary organizations," such as the People's Democratic Front for the Liberation of Palestine and the Palestine Liberation Organization (PLO).

When meeting the first PLO delegation to China in March 1965 Mao said: "Imperialism is afraid of China and of the Arabs. Israel and Formosa are bases of imperialism in Asia. You are the front gate of the great continent, and we are the rear. They created Israel for you and Formosa for us"14. Put differently, fighting imperialism in East Asia undermines its hold on the Middle East while fighting imperialism in the Middle East undermines its hold on East Asia. This is the fundamental logic of the Chinese policy in the Middle East. Iran provides the best example. Beijing's backing for Iran's nuclear program is not based on any particular friendship or identification with the Iranian policies and is certainly not directed against Israel. Iran's oil, trade and investments are definitely important but could be substituted (e.g. by Saudi Arabia). Similarly, Beijing's backing of the Assad regime in Syria by no means reflects any sympathy, nor economic benefits or a pursuit of energy -and the same goes

11 Yitzhak Shichor, The Middle East in China's Foreign Policy 1949-1977 (London and New York: Cambridge University Press, 1979). Reprinted 1981, digitally printed version 2008, pp. 9-11.

12 Shichor, The Middle East in China's Foreign Policy, pp. 38-39, 86, 107.

13 Ibid.

${ }^{14}$ Quoted by John K. Cooley, Green March, Black September: The Story of the Palestinian Arabs (London: Frank Cass, 1973), p. 176.

Araucaria. Revista Iberoamericana de Filosofia, Política y Humanidades, año 18, nº 35. Primer semestre de 2016. Pp. 319-339. ISSN 1575-6823 e-ISSN 2340-2199 doi: 10.12795/araucaria.2016.i35.16 
for Sudan. Using proxies, Beijing actually aims at the US in retaliation for its defense relations with Taiwan (and support for its separate existence) and military presence in East Asia. Beijing could hardly respond to the US arms sales to Taiwan, but it could -and did- respond in the Middle East, blocking or delaying agreements on Iran's nuclear program or shielding Bashar Assad in Syria and Omar al-Bashir in Sudan, against US intentions. Thus, the links between East Asia and the Middle East in China's foreign policy could be perceived as connected vessels or in terms of yin-yang dialectics. China appears to uphold the traditional and modern balance of power principle, whereby the US should diminish its presence in East Asia so as to allow China to restore its time-honored role as the region's hegemon -in return for its more cooperative policy in other regions, including the Middle East.

Actually, Beijing's counter-US policy in the Middle East has little to do with the Middle East and apparently does not represent any attempt to drive the US away from the region or to substitute it as a regional hegemon. Implicitly, Beijing welcomes US presence in the region and its role in preserving regional stability. Moreover, China prefers that the US will stay entangled and embroiled in the Middle Eastern conflicts and problems -far away from East Asia. So why undermine US interests in the region? The key to answer this question is to be found not in the Middle East but in East Asia and has to do with the time-honored conceptions of spheres of influence and balance of power. In fact, Beijing does not have a "Middle East policy"; its Middle East policy is a derivative of its general foreign policy and, in particular, its relations with the US in East Asia.

The main other region where the strategic interests of the US and China actually clash is the Middle East. In the past Beijing implicitly considered the US presence in East Asia - and the Middle East- as promoting regional stability and thereby conforming to Chinese interests. This is no longer the case. Many Chinese experts now consider US presence in East Asia and the Middle East as undermining regional stability. Yet, while it would not say it publicly, Beijing doesn't mind if the US continues its presence in the Middle East - but certainly not in East Asia ${ }^{15}$. In fact, in his meeting with Henry Kissinger in November 1973, Mao Zedong "encouraged U.S. military involvement in the Middle East to counter the Soviets"16. Beijing does not want to replace the US in the Middle East - or anywhere else, except for East Asia. Its policy in both regions is mainly negative and contradictive; its power lies not in its ability and willingness to facilitate settlements and agreements but in its ability and willingness to obstruct and delay settlements and policies which the US tries to

15 Zhang Jiadong, "Zhong Mei zai zhongdong de gongtong liyi yu fenqi" [Common Interests and Differences of China and the US in the Middle East], Alabo Shijie Yanjiu [Arab World Studies], No. 2 (March 2007), pp. 50-59.

${ }^{16}$ Henry Kissinger, On China (New York: The Penguin Press, 2011), p. 282. 
enforce and promote ${ }^{17}$. Even in the case of Iran, ultimately relations with the US are more important. Talking to Agence France Presse, Ji Kaiyun, an expert on Sino-Iranian relations at Chongqing Southwest University, made the following comment in June 2006: "China will not challenge, and China does not aim to transform, the U.S.-led international order. Sino-American ties take precedence over Sino-Iranian ties. China will not clash with the United States over Iran"18. Iranian scholars, and probably officials, are aware of China's international priorities. In sum, East Asia and West Asia should be regarded as connected vessels in China's strategic outlook: Beijing's behavior in the Middle East is not just related to, but also conditioned by, the situation in East Asia.

\section{The Economic Connection}

In a statistical perspective, the share of the Middle East in China's international economic relations is relatively small. In 2013 the greater Middle East contributed 7.2 percent to the Chinese foreign trade (the US share was 12.5 percent $)^{19}$. Evidently, the main significance of the Middle East for China is as a source of crude oil, to be discussed below. Still, in spite of its reliance on crude oil imports from the Middle East, the share of imports from the greater Middle East was 8.2 percent of China's total imports, which means that China has managed almost to balance its Middle Eastern export and import. In fact, this region is important not just as an "end user" of Chinese exports but also, and perhaps even more important, as a springboard or junction for other markets, primarily in Europe but also in Africa and the Mediterranean. As such, it is an invaluable and indispensable component of China's leader Xi Jinping's acclaimed One Belt One Road (or New Silk Road) policy. This policy actually relies on two Silk Roads -the continental and the maritime- both of which converge in the Middle East. Although at this stage this policy is still no more than a vision and it is doubtful if China would invest the huge capital needed for implementing this vision, it does nevertheless follows China's current policies. There is nothing new in China's OBOR policy, except for its name. Earlier labelled "go west," this policy targets Central Asia and the Middle East as a

17 Following the Party line, Chinese scholars say that the main difference between the two is that while the US tries to promote democracy and liberalism that lead to negative outcomes, China promotes "peace and harmony" with a positive contribution. See: Jin Liangxiang, "Zhong Mei zhongdong zhengce bijiao: linian, zhengce yu gongxian" [A Comparison of China and US Middle East Policy: Principle, Policy and Contribution], Guoji Zhanwang [Global Review], Vol. 5, No. 4 (July-August 2013), pp. 68-81.

18 Quoted in: Yitzhak Shichor, "Disillusionment: China and Iran's Nuclear Gamble," Freeman Report, (Washington: Center for Strategic and International Studies, Georgetown University: JulyAugust 2006), p.3.

19 National Bureau of Statistics of China, China Statistical Yearbook 2014 (Beijing: China Statistical Press, 2014), pp. 337-338.

Araucaria. Revista Iberoamericana de Filosofía, Política y Humanidades, año 18, n 35. Primer semestre de 2016. Pp. 319-339. ISSN 1575-6823 e-ISSN 2340-2199 doi: 10.12795/araucaria.2016.i35.16 
continental bridge. With or without this label, the Middle East is indispensable for China's economic interaction with Europe. Turkey is an example.

Over the last two decades China has invested heavily in Turkey, penetrating its economy, buying Turkish industries in order to enjoy Turkey's trade quotas for reaching European markets ${ }^{20}$. At the same time, and in order to improve their westwards trade channels, the Chinese have also been engaged in the construction of transportation and communication infrastructures which could serve not only its economic but also its strategic interests. For this reason Beijing has also been interested in gaining a foothold in Israel's railroad system (primarily the section from the port of Eilat on the southern Red Sea coast to the northern ports of Haifa, Ashdod and Ashkelon on Israel's Mediterranean coast). Another object of Chinese attention has been the Suez Canal which Beijing plans to incorporate into its new OBOR policy. "China's future still depends on the Suez"21. A debate is going on in Israel about the implications of China's investments, also in some major companies in the field of food and minerals. Some, like former Mossad head Efraim Halevy, warn that China is gaining a strategic foothold in Israel that could harm its relations with some neighboring countries like Egypt. Others say that China is primarily interested in economic gains, but all agree that the Middle East and the eastern Mediterranean are becoming increasingly important for China's economic growth.

\section{The Energy Connection}

For the first twenty years since its foundation, China was a net crude oil importer, mostly from the Soviet Union and Eastern Europe (especially Romania). Throughout these years (the 1950s and the 1960s) China (with considerable Soviet help) had invested heavily in oil exploration and oilfield development, so that by the next twenty years (the 1970s and the 1980s) China became a net oil exporter. However, as the Chinese economy began to grow, the need for crude oil increased and, although still a net oil exporter, China began to import oil, primarily from Southeast Asia. By the mid-1990s as domestic output could no longer keep pace with the economic growth, China became a net importer, first of oil products and then of crude oil. Concerned about Middle Eastern instability and, therefore, about the perceived unpredictability of future

${ }^{20}$ More details in: Yitzhak Shichor, "China and Turkey in the Post-Cold War World: Great Expectations," in: Bruce Gilley and Andrew O'Neil (Eds.), Middle Powers and the Rise of China (Georgetown University Press, 2014), pp. 192-212.

${ }^{21}$ Emma Scott, "China's Silk Road strategy: A Foothold in the Suez, But Looking to Israel," China Brief, Vol. XIV, Issue 19 (10 October 2014), p. 13. See also: "The World Is Not Enough: Egypt's New Suez Canal Conjoins Chinese Silk Road," in: http://sputniknews.com/business/20150807/1025506576. html, and: "Egypt's New Suez canal to Give China More Investment Chances, Ex-Envoy," China Daily, 27 July 2015. 
oil supply and anxious to avoid dependence on one region, Beijing tried to diversify its oil import as much as possible and as far away from the Middle East. In addition, to reduce its dependence on oil import Beijing decided to buy stakes in existing oilfields abroad so as to guarantee oil supply in the future. Crude oil produced in overseas oilfields partly (or wholly) owned by China was registered in the Chinese statistical records as "domestic output".

Soon, however, Beijing was forced to change the map of its oil suppliers. For one reason, China's economy was growing so fast that small overseas crude suppliers could no longer satisfy the increased demand. The Middle East could. For another reason, Beijing came to the conclusion that the mid1970s "oil crisis" -when Middle Eastern producers imposed an oil embargo on customers considered pro-Israel- would not be repeated. In fact, most oil supply disruptions since then have been caused by customers - not by suppliers. Like many other countries, by the early $21^{\text {st }}$ century the Chinese turned more and more to the Middle East for their oil supply, based on the assumption that Persian Gulf oil would last for many decades. Two things should be underlined. For one, China's reliance on Persian Gulf oil is still relatively low at around 55 percent or less -compared to the much heavier dependence of other East Asian countries like Japan and South Korea. For another, China will increase its reliance on oil import from the Persian Gulf as its economy grows, even at lower rates. In fact, China's oil imports over the last two years (2014-2015) have been considerably higher than GDP growth, despite the economic slowdown. This increase is not only related to domestic consumption; it reflects China's refining overcapacity and its policy of exporting oil products and condensates. In addition, the Saudis invested in the expansion, renovation and construction of Chinese oil refineries, adapted to refine Saudi crude, which point to longterm energy connections between these two countries. In other words, China's future economic growth is solidly interconnected to the Middle East, for a long time to come. It is, however, threatened by terrorism, both at sea and on land, to be discussed below.

\section{The Military Connection}

At a first sight, the Middle East has no military value for China and does not figure much, if at all, in China's national defense considerations. Nonetheless, the Middle East played a crucial role in the initial stages of post-Mao China's military modernization and is still playing an indispensable role that no other region in the world does. The Middle East is significant for China's military modernization, first, in terms of a market for export and for generating income for defense modernization. From the late 1970s until the late 1980s the Middle East 
was China's primary market for arms sales. While earlier Chinese arms had been delivered to neighboring countries on the basis of strategic considerations rather than economic ones, or to national liberation movements based on ideology, following Mao's death Beijing has decided to sell arms for commercial reasons to regions far away from its borders and from its security concerns. This policy change was first applied to the Middle East. From 1979 to 1990 the value of Chinese arms sold to the Middle East is estimated at nearly US\$8.8 billion, nearly 58 percent of China's total arms sales in that period. In certain years (e.g. 1984 and 1985) Iraq, Iran and Egypt alone acquired over 80 percent of all Chinese arms sales. ${ }^{22}$ No open information is available as to the uses of this income but it was probably channeled back into China's military industries and defense complex -at a time when defense had been accorded the lowest priority among the Four Modernizations. Therefore, it seems that the first injection of funds for post-Mao China's defense modernization came from the Middle East.

Secondly, the Middle East was not only the first to provide China with funds but also the first to provide China with advanced military technology. Through its military relations with Arab countries, and especially Egypt -now alienated from the Soviet Union- China managed to gain access to more advanced Soviet military technology and was also given samples of weapons it could not get from Moscow since the early 1960s, including MiG-21 fighters. All these, however, were marginal compared to Beijing's acquisition of arms and military technology from Israel since the early 1980s. Israel had not only developed some of the most advanced military systems in the world, but was the only one with rich experience in coping with Soviet weapons and, moreover, in upgrading Soviet weapons and incorporating them into Israel Defense Force (IDF). Beijing's defense establishment had been watching Israel's military achievements for years, long before official, and even unofficial, relations were established. Also and unlike other Western suppliers, Israel was ready to sell China not just off-theshelf weapons (for which Beijing at that time did not have enough funds) but also military technology that the Chinese could use to produce by themselves. Indeed, for over twenty years China produced a variety of weapons based on Israeli design and technology -yet under Chinese names- which have been deployed by the People's Liberation Army (PLA) ${ }^{23}$.

22 SIPRI Arms Transfers Database, accessed on December 7, 2015. See also: Yitzhak Shichor, "Unfolded Arms: Beijing's Recent Military Sales Offensive," The Pacific Review, Vol. I, No. 3 (October 1988), pp. 320-330 and: Bates Gill, Chinese Arms Transfers: Purposes, Patterns, and Prospects in the New World Order (Westport, CT: Preager, 1992), and Daniel L. Byman and Roger Cliff, "China's Arms Sales: Motivations and Implications,” Report MR-1119-AF (RAND Corporation, 1999).

23 On Israel's arms sales to China, see: Yitzhak Shichor, "Israel's Military Transfers to China and Taiwan," Survival, Vol. 40, No. 1 (Spring 1998), pp. 68-91; Bates Gill and Taeho Kim, China's Arms Acquisitions from Abroad: a Quest for 'Superb and Secret Weapons', SIPRI Research Reports No. 11 (Oxford: Oxford University Press, 1995). 
Since the early 1990s, both contributions to China's defense modernization have actually ended. As other markets for Chinese arms have become available (primarily in Africa and South Asia) the share of the Middle East in China's arms sales has declined. Needless to say, given its phenomenal economic growth, China's defense modernization is no longer dependent on income generated from arms sales. Also, the significance of Israeli military technology transfers to China has declined considerably for three main reasons. To begin with, the resumption of Sino-Russian "friendship" following the Soviet collapse provided for accelerated military acquisitions from Moscow. These acquisitions are responsible for the end of Israeli military supplies to China, but only partly. A more significant reason is Washington's decision to force Israel to stop its arms sales to China, a process that began in the early 1990s and ended in the mid-2000s. While the considerations behind this US decision are beyond the scope of this article, and were discussed elsewhere, the outcome is not. Despite Beijing's continued interest in Israel's military technology, Israel does not supply China with military hardware or software any more. Finally, based on its scientific and technological progress, China is becoming substantially less dependent on external sources of military supply. Over the last two decades China's defense industrial complex has turned out advanced military systems reflecting impressively growing capabilities. Therefore, as far as China's two-way military transactions are concerned, the Middle East is no longer a factor in China's defense considerations. It still is, however, in another respect: lessons in advanced warfare.

China's last engagement in war, however limited, was in Vietnam in 1979, when China's post-Mao reforms had been launched, and since then -for over 35 years, more than one third of a century- the PLA has not experienced real fighting. One way to overcome this predicament is to watch other military confrontations - primarily those involving China's potential adversaries- learn and adopt the relevant lessons. In this respect, of all regions the Middle East is second to none. It is indeed a "region of war" 24 . Since the beginning of China's reform there have been a number of military confrontations in the Middle East, a source of indispensable significance for China's defense modernization. Those involved, primarily the US and Western Europe, but also Israel and other actors, have exposed and displayed -free of charge- their most sophisticated military technologies and advanced warfare techniques - extensively covered by the media for all to see. All Beijing had to do, as the old proverb goes, was "to sit on top of the mountain and watch the tigers fight" (zuoshan guan hudou). These Middle Eastern military lessons are priceless for Beijing's defense modernization. Russia's recent military involvement in Syria added another one. Although China and Russia appear to be allies and partners, underneath

${ }^{24}$ Douglas Lemke, Regions of War and Peace (Cambridge: Cambridge University Press, 2002). 
this "friendship" there are mutual suspicions fed by years of mistrust going back to the $17^{\text {th }}$ century. Both have allegedly settled their territorial conflicts by signing border agreements, but Beijing never forgets. China's public dislike of Russia (by no means an official policy) is evident in many websites and blogs, some of which could barely hide their joy at the downing of Russia's Sukhoi-24 bomber by a Turkish Air Force US-made F-16 fighter on November 24, $2015^{25}$.

\section{The Islamic Connection}

Statistically China should not have an Islamic problem. According to the 2010 population census China had about 22.5 million Muslims, around 1.6 percent of China's population, mostly Sunni (only the Tajiks are Shi'ite, numbering no more than 52,000). Furthermore, China's Muslims are divided by at least ten different ethnic groups among whom there is little, if any, solidarity. They are scattered over 19 of China's provinces and autonomous regions although the two main groups (Hui, about 10.6 million) and Uyghurs (about 10.1 million) constitute some 92 percent of China's total Muslim population. Whereas the Hui originate from ethnically Chinese Muslims who-despite serious clashes and uprisings in the past- now tend to cooperate with the Government, Uyghurs are of ethnically Turkic stock that, unlike other Turkic nationalities in China, do not have a homeland beyond the border. In 1955 they were accorded the PRC's first autonomous region, where their past, present and future look distressing if not tragic.

Having constituted about 95 percent of Xinjiang's population when the Communists had taken over the province in 1949, they are now less than a half following years of Chinese migration that has upset the demographic balance and turned the majority Uyghurs into a minority. Brutally suppressed from the 1950 s to the 1980s, Uyghur unrest in Xinjiang has begun to gather momentum in the wake of China's post-Mao reform that allowed for limited liberalism and especially since the collapse of the Soviet Union, the independence of the Central Asian republics, and the opening of the long border. Initially, much of the Uyghur struggle had been triggered by nationalist feelings -supplemented by policies of political, social and economic discrimination. In recent years, however, following the rise of Islamic fundamentalism in Central Asia and the Middle East, Uyghur protest has also been motivated by religious persecution and prohibitions. Whatever the reasons, since the early 1990s there have been a number of violent incidents between Uyghurs and Chinese internal security

\footnotetext{
${ }^{25}$ Personal communication by a professor from China. See also: Dean Cheng, "Chinese Lessons from the Gulf Wars," in: Andrew Scobell, David Lai and Roy Kamphausen (Eds.), Chinese Lessons from Other Peoples' Wars (Carlisle Barracks, PA: Strategic Studies Institute, US Army War College, November 2011), pp. 153-199.
} 
authorities, where many (Uyghurs and Chinese) were killed or wounded. Many Uyghurs were arrested, jailed and executed which further fueled unrest in Xinjiang.

From the very beginning the Chinese had insisted that unrest in Xinjiang (and elsewhere) is an internal Chinese problem in which no outsiders are allowed to interfere. Still, it did not take long for the Chinese to realize the external origins of Xinjiang's unrest. Much of this exogenous intervention has come from Central Asia - especially from Pakistan and Afghanistan. But as the Islamic component of this unrest has increased, accompanied by acts of terrorism, the Middle East has also represented an influential input. Already in the 1990s, Iran and Saudi Arabia had begun to actively support China's Islam by transferring funds and religious books for mosques and madrassahs. Beijing was quick to tell both to mind their own business and stop interfering in China's internal affairs - which they did. This, however, did not stop the flow of religious literature, cassette tapes, compact discs - and to some extent also funds, explosives and weapons- smuggled across the border and, allegedly, reached terrorist hands inside Xinjiang.

However, the Internet, computer-mediated-communication, websites and blogs disregard physical borders. Radical Islamic organizations that are sheltered in Central Asia and the Middle East actively (though in fact virtually) support violent unrest not only in Xinjiang but also in other parts of China, as well as in areas outside China, especially in those regions currently ruled by the Islamic State. Noteworthy among these organizations is the Turkistan Islamic Party (TIP $)^{26}$ that regularly condemns China for its treatment of Islam in general and Uyghurs in particular. Online jihadi websites and magazines blamed China for its "atrocities" against Muslims and for its policy of "obliterating" Islamic culture and institutions. Moreover, they vowed "to kill the Communist Chinese" wherever they could be found. And they were. In November 2015 ISIS online magazine Dabiq reported that a Chinese captive had been executed. Other online magazines such as Sawt al-Islam (Voice of Islam, Uyghur version - Islam Awazi), provided instructions for producing explosives and weapons and claimed responsibility for a number of violent incidents (although there is no evidence for that) ${ }^{27}$.

Given China's tight control over Xinjiang, the distance from the Middle East and the fact that ISIS and other extremist Islamic organizations are fighting

${ }^{26}$ Kirk H. Sowell, "Promoting Jihad against China: The Turkistani Islamic Party in Arabic Jihadist Media," (An Independent Report Commissioned by Sky News, 1 August 2010).

27 "Islamic State Says It has Executed Two Captives from Norway and China," Reuters (Cairo), November 19, 2015; Michael Martina, “Around 300 Chinese Fight alongside ISIS,” Reuters (Beijing), December 15, 2014; Yitzhak Shichor, "See No Evil, Hear No Evil, Speak No Evil: Middle Eastern Reactions to Rising China's Uyghur Crackdown," Griffith Asia Quarterly, Vol. 3, No. 1 (January 2015), pp. 62-85. See also: “Ten Facts about East Turkistan," Resurgence (The Magazine for a resurgent Muslim Umma), Issue 1 (Fall 2014), pp. 44-45. 
regional and international forces, it is unlikely that their threat to China is real or immediate. Still, the real threat is less in actual involvement in violent incidents and more in ideological contamination that -very much like the Internet- has no physical bounds. Undoubtedly concerned about an Islamic threat, Beijing is using it and even inflating it to justify and legitimize its efforts to suppress Uyghur unrest -part of it generated by religious persecution ${ }^{28}$. Nevertheless, there is an undeniable connection between Middle Eastern Islamic militancy and China's internal stability. Islamic terrorism (and piracy) also threatens China's energy supply both at sea and on land. Radical Islamic publications target the oil chokepoints in and around the Middle East through which most of China's oil is shipped to feed its thirsty economy, hinting at forthcoming terrorist $\operatorname{acts}^{29}$.

\section{Conclusion}

Officially, Beijing tries to avoid public criticism about the Middle East and also applies its non-intervention policy to this region. Unofficially, the government, and much more so academic writings, often displays discontent and ill-feelings about various aspects of the Middle East. Never explicitly defined in such a way, the Middle East provides a negative model for China, an example that should be a warning. Called in the past "hot spot," the region is regarded as a source of instability, internal and inter-state conflicts, social and religious splits, and economic failures that invite external intervention contrary to China's interests. It is also a source of Islamic radicalism and terrorism and a good example of the failure of democracy and liberalism. At the same time, many Middle Eastern countries do represent antiquated, backward and orthodox regimes -terms that the Chinese used when referring to the Middle East in the early 1950s. These terms are no more in use, but their content appears to survive. Under these circumstances, why should Beijing play a more active role in the Middle East or even become the new hegemon, replacing the US?

Over the last few years a number of media and academic publications pointed out that the Chinese have become much more active in the Middle East. To some extent, these views reflect Chinese scholars' impatience with China's regionalized foreign policy and advice that China should abandon its "nonintervention" policy and play a more proactive role in international affairs, including in the Middle East ${ }^{30}$. These views converge with those of Western

\footnotetext{
${ }^{28}$ Gary Sands, "China and the ISIS Threat," The Diplomat, 26 September 2014.

29 Hamza Khalid, "On Targeting the Achilles Heel of Western Economies," Resurgence, Issue 1 (Fall 2014), pp. 94-104. Although the emphasis is on Western vulnerability, Asian and Chinese destinations of Middle Eastern oil are mentioned.

${ }^{30}$ Chen Dinging and Wang Jianwei, "Lying Low No More? China's New Thinking on the Tao Guang
} 
analysts who perceive that the US role in the world is in a process of decline and weakness -especially in the Middle East whose crude oil is allegedly "no longer needed" by the US. Allegedly, the so-called "US withdrawal" from the Middle East creates a void for the Chinese to fill ${ }^{31}$. All these assumptions and conclusions miss important points. In fact, China's Middle East policy has not changed fundamentally. To be sure, like in other regions in the world, China's economic activism has increased and diversified, and some symbolic actions have been taken (e.g. in UN peacekeeping forces, the struggle against piracy, participation in military exercises, and occasional though inconsequential visits by Beijing's "special envoys") but the Chinese still avoid active involvement, not to mention mediation, in regional conflicts ${ }^{32}$, and for good reasons.

To begin with, despite the close relations between research institutes and the government in China, Beijing's decision-makers rarely base their policies on academic papers. While scholarly opinions and suggestions reach the leadership, they are not necessarily adopted and, although being frequently quoted by Western researchers (myself included), they by no means reflect Beijing's policy. Also, the conventional wisdom about a US withdrawal from the Middle East, because of oil "self-sufficiency" or for other reasons (the policy of "pivoting" or "rebalancing" to East Asia), does not hold water. The US is still and will be for a long time to come, if not forever -dependent on Middle Eastern oil, not to mention other strategic considerations. There is no reason for China to become involved in settling Middle Eastern problems and thereby undermine its policy of maintaining good relations with all Middle Eastern countries -including those in conflict, which means all or nearly all of them. And, if Washington proceeds with its pivoting or rebalancing policy to East Asia, the Chinese have even less incentive to collaborate with the US

\footnotetext{
Yang Hui [literally: 'Hide brightness, nourish obscurity' or: 'mind our own business and be humble in world affairs'] Strategy", China: an International Journal, Vol. 9, No. 2 (September 2011), pp. 195 216; Wang Jisi, "'Marching Westwards': The Rebalancing of China's Geostrategy," International and Strategic Studies Report, No. 73 (Center for International and Strategic Studies, Peking University, 7 October 2012); Wang Yizhou, “'Creative Involvement': A New Direction in Chinese Diplomacy,” in: Mark Leonard (Ed.), China 3.0 (London: European Council on Foreign Relations, November 2012), pp. 106-111; Zhou Shixin, "Zhongguo dui zhongdong bianju de jianshexing jieru” [Strategic Thinking on China's Constructive Involvement in the Middle East Turmoil], Alabo shijie yanjiu [Arab World Studies], No. 2 (March 2013), pp. 40-52, and: Yan Xuetong, "From Keeping a Low Profile to Striving for Achievement," The Chinese Journal of International Politics, Vol. 7, No. 2 (2014), pp. 153-184.

31 "Beijing Eyes Broader Role in Middle East," South China Morning Post, 10 January 2014; Zachary Keck, "China Wants to Join Middle East Peace Quartet," The Diplomat, 15 January 2014; Muhammad Zulfikar Rakhmat, "Why China Could Be Effective in the Middle East," The Diplomat, 20 February 2014; Abbas Varij Kazemi and Xiangming Chen, "China and the Middle East: More Than Oil," The European Financial Review, 21 February 2014; Andy Polk, "China: A Major Power in the Middle East?" War on the Rocks, 5 March 2014; Paul Rivlin, "Will China Replace the U.S. in the Middle East?" Iqtisadi: Middle East Economy, Vol. 4, No. 3 (25 March 2014).

32 For more details see: Yitzhak Shichor, "Fundamentally Unacceptable yet Occasionally Unavoidable: China's Options on External Intervention in the Middle East," China Report, Vol. 49, No. 1 (2013), pp. 25-41.
} 
in the Middle East, even though they occasionally have done so (e.g. in the 1990-91 Gulf War and in the UN Security Council). Certainly as long as the US continues to maintain - or even more so, expand- its military presence in East Asia. Beijing's behavior indicates that in its strategic outlook the Middle East and East Asia are connected vessels. 


\section{Bibliography:}

Annual Arab Public Opinion Polls 2006-2011, University of Maryland.

"Beijing Eyes Broader Role in Middle East," South China Morning Post, 10 January 2014.

Charles, T. Multiculturalism: Examining the Politics of Recognition (Princeton: Princeton University Press, 1994).

Chen, D. G. and Wang J. W. 'Lying Low No More? China's New Thinking on the Tao Guang Yang Hui [literally: 'Hide brightness, nourish obscurity' or: 'mind our own business and be humble in world affairs'] Strategy," China: an International Journal, Vol. 9, No. 2 (September 2011), pp. 195-216.

Cheng, D. "Chinese Lessons from the Gulf Wars," in: Scobell, A., Lai, D. and Kamphausen, R. (eds.), Chinese Lessons from Other Peoples' Wars (Carlisle Barracks, PA: Strategic Studies Institute, US Army War College, November 2011), pp. 153-199.

Cooley, J. K. Green March, Black September: The Story of the Palestinian Arabs (London: Frank Cass, 1973).

Cotterell, Arthur. Western Power in Asia: Its Slow Rise and Swift Fall, 1415 1999 (New York: John Wiley, 2009).

Deng, Y. and Moore, T. G. "China Views Globalization: Toward a New greatPower Politics?", The Washington Quarterly, Vol. 27, No. 3 Summer (2004), pp. 117-136.

"Egypt's New Suez Canal to Give China More Investment Chances, ExEnvoy," China Daily, 27 July, 2015.

Gill, Bates and Kim T. China's Arms Acquisitions from Abroad: a Quest for 'Superb and Secret Weapons', SIPRI Research Reports No. 11 (Oxford: Oxford University Press, 1995).

Gill, B. "China Becoming a Responsible Stakeholder," 21 June, 2007, in: www. carnegieendowment.org/files/Bates_paper.pdf.

Gill, B. Chinese Arms Transfers: Purposes, Patterns, and Prospects in the New World Order (Westport, CT: Preager, 1992), and Byman, D. L. and Cliff, R. “China's Arms Sales: Motivations and Implications," Report MR-1119AF (RAND Corporation, 1999).

Goldstein, J. and Shichor, Y. (eds.) China and Israel, 1948-2015 (Jerusalem: the Magnes Press, 2016), in Hebrew.

Gurtov, M. "The Uncertain Future of a 'New Type' of US-China Relationship," The Asia-Pacific Journal, Vol. 11, Issue 52, No. 1 (30 December 2013).

Hu, A.G. China in 2020: A New Type of Superpower (Washington: The Brookings Institute, 2011).

"Islamic State Says It has Executed Two Captives from Norway and China," Reuters (Cairo), 19 November 2015. 
Jin, L.X. "Zhong Mei zhongdong zhengce bijiao: linian, zhengce yu gongxian" [A Comparison of China and US Middle East Policy: Principle, Policy and Contribution], Guoji Zhanwang [Global Review], Vol. 5, No. 4 (JulyAugust 2013), pp. 68-81.

Kazemi, A. V. and Chen, X. M. "China and the Middle East: More Than Oil," The European Financial Review, 21 February 2014.

Keck, Z. "China Wants to Join Middle East Peace Quartet," The Diplomat, 15 January 2014.

Khalid, H. "On Targeting the Achilles Heel of Western Economies," Resurgence, Issue 1 (Fall 2014), pp. 94-104.

Kissinger, H. On China (New York: The Penguin Press, 2011).

Lemke, D. Regions of War and Peace (Cambridge: Cambridge University Press, 2002).

Martina, M. “Around 300 Chinese Fight alongside ISIS," Reuters (Beijing), 15 December 2014.

Mearsheimer, J. J. “The Gathering Strom: China's Challenge to US Power in Asia," The Chinese Journal of International Politics, No. 3 (2010), pp. 381-396.

National Bureau of Statistics of China, China Statistical Yearbook 2014 (Beijing: China Statistical Press, 2014), pp. 337-338.

Pew Research Center. “America's Global Image Remains More Positive than China's, But Many See China Becoming World's Leading Power," 18 July, 2013.

Polk, A. "China: A Major Power in the Middle East?" War on the Rocks, 5 March 2014.

Rakhmat, M. Z. "Why China Could Be Effective in the Middle East," The Diplomat, 20 February 2014.

Rivlin, P. "Will China Replace the U.S. in the Middle East?" Iqtisadi: Middle East Economy, Vol. 4, No. 3 (25 March 2014).

Sands, G. "China and the ISIS Threat," The Diplomat, 26 September 2014.

Schweller, R. L. and Pu X.Y. "After Bipolarity: China's Vision of International Order in an Era of U.S. Decline," International Security, Vol. 36, No.1 Summer (2011), pp. 41-72.

Scott, E. "China's Silk Road strategy: A Foothold in the Suez, But Looking to Israel," China Brief, Vol. XIV, Issue 19 (October 10, 2014).

Shichor, Y. "China and Turkey in the Post-Cold War World: Great Expectations," in: Gilley, B. and O’Neil, A. (eds.), Middle Powers and the Rise of China (Washington: Georgetown University Press, 2014), pp. 192-212.

Shichor, Y. "Chinese-Israeli Relations in a Middle Eastern Context: Retrospect and Prospects,” Mediterranean Quarterly, Vol. 26, No. 1 March (2015), pp. 137-151. 
Shichor, Y. "Disillusionment: China and Iran's Nuclear Gamble," Freeman Report, (Washington: Center for Strategic and International Studies, Georgetown University: July-August 2006).

Shichor, Y. "Fundamentally Unacceptable yet Occasionally Unavoidable: China's Options on External Intervention in the Middle East," China Report, Vol. 49, No. 1 (2013), pp. 25-41.

Shichor, Y. "Israel's Military Transfers to China and Taiwan," Survival, Vol. 40, No. 1 (Spring 1998), pp. 68-91.

Shichor, Y. "See No Evil, Hear No Evil, Speak No Evil: Middle Eastern Reactions to Rising China's Uyghur Crackdown," Griffith Asia Quarterly, Vol. 3, No. 1 January 2015), pp. 62-85.

Shichor, Y. "Sino-American Crosscurrents in the Middle East: Perceptions and Realities," in: Horesh, N. (ed.), Toward Well-Oiled Relations? China's Presence in the Middle East following the Arab Spring (New York: Palgrave Macmillan, 2015).

Shichor, Y. The Middle East in China's Foreign Policy 1949-1977 (London and New York: Cambridge University Press, 1979). Reprinted 1981, digitally printed version 2008.

Shichor, Y. "Unfolded Arms: Beijing's Recent Military Sales Offensive," The Pacific Review, Vol. I, No. 3 (October 1988), pp. 320-330.

SIPRI Arms Transfers Database.

Sowell, K. H. "Promoting Jihad against China: The Turkistani Islamic Party in Arabic Jihadist Media," (An Independent Report Commissioned by Sky News, 1 August 2010).

"Ten facts about East Turkistan," Resurgence (The Magazine for a resurgent Muslim Umma), Issue 1 (Fall 2014), pp. 44-45.

"The World Is Not Enough: Egypt's New Suez Canal Conjoins Chinese Silk Road,” in: http://sputniknews.com/business/20150807/1025506576.html.

Wang, J. S. "'Marching Westwards': The Rebalancing of China's Geostrategy," International and Strategic Studies Report, No. 73 (Beijing: Center for International and Strategic Studies, Peking University, 7 October 2012).

Wang, Y. Z. "'Creative Involvement': A New Direction in Chinese Diplomacy," in: Leonard, M. (ed.), China 3.0 (London: European Council on Foreign Relations, November 2012), pp. 106-111.

Womack, B. "Asymmetry Theory and China's Concept of Multipolarity," Journal of Contemporary China, Vol, 13, No. 39 May (2004), pp. 351366;

Yan, X. T. "From Keeping a Low Profile to Striving for Achievement," The Chinese Journal of International Politics, Vol. 7, No. 2 (2014), pp. 153184. 
Zhang, J.D. "Zhong Mei zai zhongdong de gongtong liyi yu fenqi" [Common Interests and Differences of China and the US in the Middle East], Alabo Shijie Yanjiu [Arab World Studies], No. 2 March (2007), pp. 50-59.

Zhou, S. X. "Zhongguo dui zhongdong bianju de jianshexing jieru" [Strategic Thinking on China's Constructive Involvement in the Middle East Turmoil], Alabo shijie yanjiu [Arab World Studies], No. 2 (March 2013), pp. 40-52.

Zoellick, R. "Whither China: From Membership to Responsibility?" The National Committee on US-China Relations, New York, 21 September, 2005. 
